\title{
Karakterisitk Pantulan Spektral Citra Landsat 8 Pada Area Pasang Surut: Studi KasusTeluk Benoa, Bali
}

\author{
I Wayan Gede Astawa Karang ${ }^{\text {ab* }}$ \\ ${ }^{a}$ Program Studi Ilmu Kelautan, Fakultas Kelautan dan Perikanan, Universitas Udayana,Kampus UNUD Bukit Jimbaran, Badung, Bali 80361, \\ Indonesia \\ ${ }^{b}$ Center for Remote Sening and Ocean Science (CReSOS), Universitas Udayana \\ * Penulis koresponden. Tel.: +62-361-702-802 \\ Alamat e-mail: gedekarang@unud.ac.id
}

Diterima (received) 13 September 2016; disetujui (accepted) 22 Oktober 2016; tersedia secara online (available online) 29 Oktober 2016

\begin{abstract}
Benoa bay is a tidal area located in the southern part of Bali island. Several study of physical aspect of sea water in the Benoa bay has been done using remote sensing data. At this moment there aren't studies about the relationship between the tidal condition and the spectral response. For this reason, the aim of this work is to study the characteristic of spectral response of satellite data linked to tidal variation. To meet the goal, Landsat TM 8 images were used in eight different dates ranging from March 2014 to May 2015. The methodology included techniques such as radiometric corrections, cropping and statistical analysis for band 1 to 7 . The results indicate that when landsat 8 images acquired, Benoa Bay has a tidal elevation from -0.121 to 0.857 . The spectral responses for the sea water body show a contrast between the visible and infrared regions. There isn't clear correlation between tidal water variation and its spectral behavior of infrared regions; it depends rather on the presence or absence of sediments and vegetation in the water as shown in the visible region with moderate correlation 0.65 (Band 1) and 0.67 (Band 2).
\end{abstract}

Keywords: Benoa bay; remote sensing; spectral response; tidal elevation

\begin{abstract}
Abstrak
Teluk Benoa merupakan daerah pasang surut yang terletak di bagian selatan pulau Bali. Beberapa studi terkait fisika air laut di Teluk Benoa telah dilakukan dengan menggunakan data penginderaan jauh. Pada saat ini belum ada studi tentang hubungan antara kondisi pasang surut dan respon spektral. Untuk alasan ini, tujuan dari pekerjaan ini adalah untuk mempelajari karakteristik respon spektral data satelit terkait dengan variasi pasang surut. Untuk memenuhi tujuan tersebut, Landsat TM 8 dataset digunakan yang terdiri dari delapan tanggal yang berbeda mulai dari Maret 2014 sampai Mei 2015. Metodologi yang digunakan adalah koreksi radiometrik, segmentasi area dan analisis statistik untuk melihat hubungan spektral dan elevasi pasang surut. Hasil penelitian menunjukkan bahwa pada saat citra Landsat diakusisi, Teluk Benoa memiliki elevasi pasang surut dari -0,121 ke 0,857. Respon spektral area perairan menunjukkan kontras antara zona cahaya tampak dan inframerah. Tidak ada korelasi yang jelas antara variasi pasang surut air laut dan nilai replektan pada zona inframerah; hal ini tergantung lebih pada ada atau tidak adanya sedimen dan vegetasi dalam air seperti yang ditunjukkan di daerah tampak dengan korelasi sedang 0,65 (Band 1) dan 0,67 (Band 2).
\end{abstract}

Kata Kunci: Teluk Benoa; penginderaan jauh; respon spektral; elevasi pasang surut

\section{Pendahuluan}

Beberapa informasi tentang permukaan bumi dapat diturunkan dari fitur absorpsi dan emisi yang ditemukan pada signal spektral (Chang et al., 2009). Berdasarkan analisis nilai spektral, kita dapat memperoleh informasi dan karakterisitik seperti klorofil-a, struktur tanaman dan kandungan air pada daun. Selain itu juga dimungkinkan untuk mengekstrak informasi tentang permukaan seperti tipe vegetasi, tipe tutupan lahan, dan tipe batuan atau tanah (Krezhopa et al., 2007; Gangale et al., 2010). Sejumlah studi telah menunjukkan bahwa informasi dapat digunakan secara cepat, efisien dan ilustratif untuk menjelaskan dan memonitor fenomena perubahan fisik dan kimia di perairan (Decker et al., 1992; Doxaran et al.,
2002; Fan et al., 2009; Marhaba et al., 2009). Satellite dengan sensor optik merupakan teknologi terkini untuk mengukur atau merekam karaksteristik permukaan bumi berdasarkan perbedaan nilai spektral. Ekstraksi informasi spektral dari citra satellite sangat penting sebagai database optik yang akan membantu dalam memahami suatu perairan.

Area perairan yang telah banyak diteliti adalah wilayah pesisir. Wilayah pesisir merupakan area yang sangat strategis dan meiliki potensi sumber daya yang tinggi meliputi perikanan, pertambangan, pertanian, kehutanan, perhubungan, dan pariwisata. Potensi tersebut didukung oleh adanya ekosistem pesisir yang komplek mencakup perairan pantai, terumbu karang, padang lamun, mangrove, muara, delta, teluk dan daerah pasang surut. 
Namun secara fisik, karakterisitk wilayah pesisir dominan dipengaruhi oleh tinggi rendahnya muka air yang menimpanya. Perubahan level muka air disebabkan oleh adanya pengaruh pasang surut yang kuat dipesisir. Daerah teluk atau cekungan merupakan salah satu area yang memiliki perbedaan besar saat pasang dengan surut sehingga hal ini akan mempengaruhi informasi spektral pada citra satelit.

Teluk Benoa merupakan salah satu wilayah perairan yang telah banyak dikaji dalam kaitanya dengan sifat dan karakteristik perairannya. Terletak di sebelah tenggara Pulau Bali, Indonesia Teluk Benoa memiliki peran yang sangat sentral dalam menunjang industri perikanan dan perjalanan di Bali dan wilayah timur Indonesia. Pemantauan dan evaluasi terhadap status kualitas perairan Teluk Benoa baik secara fisika, biologi maupun kimia sangat diperlukan guna menunjang eksistensi peran Teluk Benoa sebagai area penyangga. Beberapa kajian telah dilakukan baik dengan menggunakan data lapangan maupun remote sensing. Diantaranya adalah penelitian tentang distribusi spasial sedimen yang terkonsentrasi di sekitar Teluk Benoa menggunakan data AVNIR-2 dari satelite ALOS (Hendrawan and Asai, 2008), karakteristik pola vertikal total padatan tersuspensi (total suspended solid) dan kekeruhan (turbidity) (Hendrawan dkk., 2016), serta studi mengenai transpor sedimen (Rachman dkk., 2016) dan pertukaran air laut (Hendrawan and Asai, 2014). Pada penelitian tersebut diperoleh bahwa sensor optik pada citra AVNIR-2dapat mengidentifikasi sebaran sedimen dengan akurasi yang cukup baik. Namun pada penelitian tersebut belum dilakukan analisis sebaran sedimen dari citra satelite untuk kondisi level air yang berbeda akibat pasang surut. Untuk itu kajian tentang karakteristik perairan Teluk Benoa dengan menggunakan citra satelit pada kondisi tinggi air yang berbeda sangat diperlukan. Sampai saat ini belum ada kajian atau penelitian tentang respon pantulan spektral citra satelit terhadap perubahan level air dan untuk alasan tersebut tujuan dari penelitian ini adalah untuk mengetahui hubungan antara karakteristik spektral air laut dan perubahan tinggi air. Pada penelitian akan menggunakan citra Landsat 8 , karena data ini telah tersedia secara online dan berbagai studi telah menunjukkan efektivitas dari citra Landsat dalam ekstraksi nilai spektral.

\section{Metode Penelitian}

\subsection{Lokasi Penelitian}

Teluk Benoa terletak di belahan selatan Pulau Bali dan berbentuk teluk intertidal yang dilingkari oleh hutan mangrove dan dilindungi dari gelombang air laut yang besar oleh Semenanjung Jimbaran di sebelah barat, Tanjung Benoa dan Pulau Serangan di sebelah timur. Teluk Benoa adalah perairan pasang surut lintas kabupaten/kota yang terletak diantara Kota Denpasar dan Kabupaten Badung. Gambar 1 menyajikan areal Teluk Benoa yang dijadikan sebagai lokasi penelitian.

\subsection{Data}

Data yang digunakan dalam penelitian ini adalah data Citra Landsat 8 seperti pada Tabel 1 dan elevasi pasang surut pada saat citra satelit diakusisi.

\section{PETA LOKASI PENELITIAN}

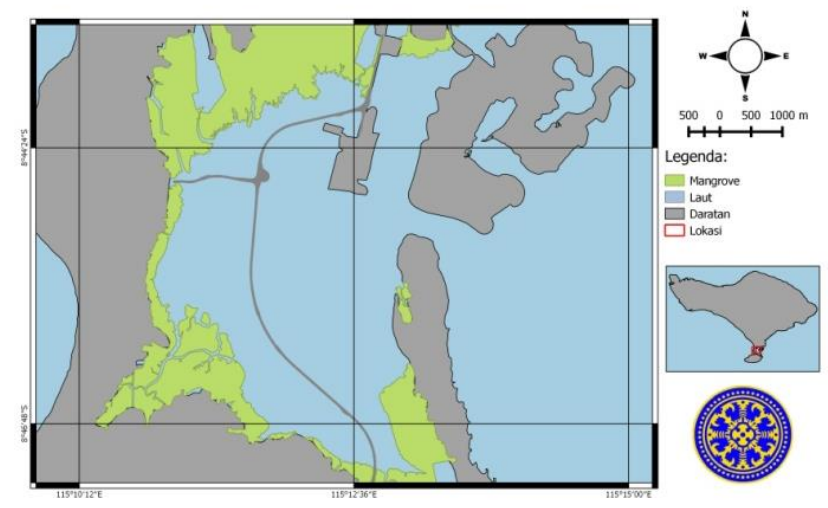

Gambar 1. Lokasi Penelitian

Tabel 1

Data citra satelit Landsat 8 yang digunakan

\begin{tabular}{cccc}
\hline No & Idenditas Data & Akuisi & $\begin{array}{c}\text { Waktu } \\
\text { (UTC) }\end{array}$ \\
\hline 1 & LC81160662014086 & $27 / 03 / 2014$ & $02: 23$ \\
2 & LC81160662014134 & $14 / 05 / 2014$ & $02: 23$ \\
3 & LC81160662015041 & $10 / 02 / 2015$ & $02: 23$ \\
4 & LC81160662015217 & $05 / 08 / 2015$ & $02: 23$ \\
5 & LC81160662015233 & $21 / 08 / 2015$ & $02: 23$ \\
6 & LC81160662015089 & $30 / 03 / 2015$ & $02: 23$ \\
7 & LC81160662015105 & $15 / 04 / 2015$ & $02: 23$ \\
8 & LC81160662015121 & $01 / 05 / 2015$ & $02: 23$ \\
\hline
\end{tabular}

Citra satelit Landsat 8 diperoleh dari website glovis.usgs.gov pada path/row adalah 116/66. Level citra yang telah di unduh yaitu L1-T (Level one - Terrain Corrected), yang telah terbebas dari kesalahan akibat sensor satelit dan bumi dan nilai pada pixel citra masih berupa Digital Number (DN) (USGS, 2016). Citra satelit Landsat 8 memiliki 11 kanal (Roy, et al., 2014) seperti Gambar 2, dimana pada penelitian ini hanya digunakan kanal 1, kanal 2, kanal 3, kanal 4, kanal 5, kanal 6, dan kanal 7.

\begin{tabular}{|llll|}
\hline Band & Description & $\begin{array}{l}\text { Wavelength } \\
\text { (micrometers) }\end{array}$ & $\begin{array}{l}\text { Resolution } \\
\text { (meters) }\end{array}$ \\
$1^{*}$ & Violet-Deep Blue & $0.43-0.45$ & 30 \\
$2^{*}$ & Blue & $0.45-0.51$ & 30 \\
$3^{*}$ & Green & $0.53-0.59$ & 30 \\
$4^{*}$ & Red & $0.64-0.67$ & 30 \\
5 & Near Infrared & $0.85-0.88$ & 30 \\
6 & Shortwave Infrared & $1.57-1.65$ & 30 \\
7 & Shortwave Infrared & $2.11-2.29$ & 30 \\
$8^{*}$ & Panchromatic & $0.50-0.68$ & 15 \\
9 & Cirrus clouds & $1.36-1.38$ & 30 \\
$10^{* *}$ & Thermal infrared & $10.62-11.19$ & 30 \\
$11^{* *}$ & Thermal infrared & $11.50-12.51$ & 30 \\
$*$ Within the visible spectrum & & \\
$* *$ 100-meter resolution data interpolated to 30 meters & \\
\hline
\end{tabular}

Gambar 2. Daftar kanal (band) pada citra satelit landsat 8 
Data elevasi pasang surut untuk wilayah perairan Teluk Benoa diperoleh dari website Intergovernmental Oceanographic Commission (IOC) (http://www.iocsealevelmonitoring.org), dengan waktu elevasi pasang surut pada saat citra Satelit Landsat 8 melewati lokasi penelitian, dimana waktu ini diperoleh dari metadata pada citra satelit Landsat 8.

\subsection{Pengolahan Data}

Proses pengolahan citra satelit Landsat 8 agar menjadi nilai rata-rata reflectance pada setiap kanal dilakukan dengan langkah-langkah seperti diagram alir pada Gambar 3. Proses pengolahan data terdiri dari koreksi rediometrik, segmentasi citra (cropping), perhitungan rata-rata nilai replektan secara spasial dan analisis data secara statistik untuk mengetahui nilai korelasi setiap Band terhadap kondisi pasang surut di perairan Teluk Benoa. Masingmasing tahapan dijelaskan pada sub berikutnya.

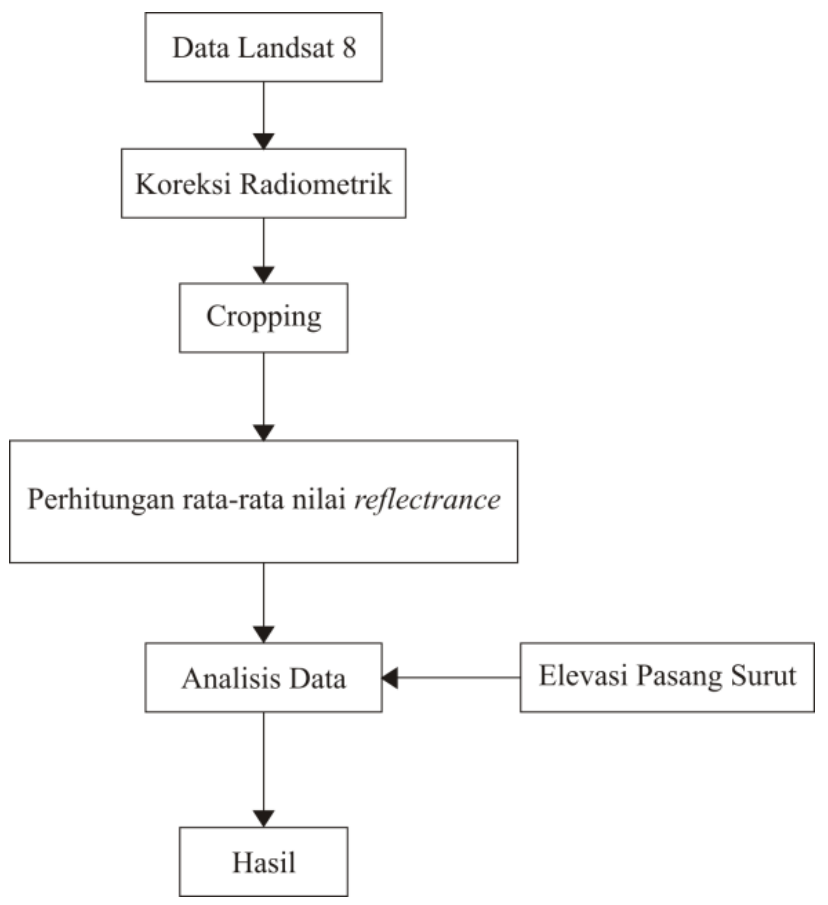

Gambar 3. Diagram alir pengolahan data

\section{a. Koreksi radiometrik}

Metode koreksi radiometrik yang digunakan pada penelitian ini adalah menggunakan koreksi Top of Atmosphere (ToA). Koreksi ToA pada sensor Operational Land Imager (OLI) dilakukan dengan mengkonversi nilai DN menjadi nilai reflectance menggunakan persamaan 1. Kemudian citra dikoreksi sudut matahari untuk menghilangkan perbedaan nilai DN yang diakibatkan oleh posisi matahari menggunakan persamaan 2. Posisi matahari terhadap bumi berubah bergantung pada waktu perekaman dan lokasi obyek yang direkam (Zanter, 2016).

$$
\begin{gathered}
\rho \lambda^{\prime}=M \rho \times Q_{\text {cal }}+A \rho \\
\rho \lambda=\frac{\rho \lambda^{\prime}}{\sin (\emptyset)}
\end{gathered}
$$

Keterangan:

$$
\begin{aligned}
\rho \lambda^{\prime}= & \text { ToA reflektansi, tanpa koreksi untuk sudut } \\
& \text { matahari } \\
M \rho= & \text { REFLECTANCE_MULT_BAND_x , di mana } \\
& \mathrm{x} \text { adalah nomor Band } \\
\mathrm{A} \rho= & \text { REFLECTANCE_ADD_BAND_x, di mana } \mathrm{x} \\
& \text { adalah nomor Band } \\
\mathrm{Q} \_ \text {cal }= & \text { Nilai digital number }(\mathrm{DN}) \\
\rho \lambda= & \text { ToA reflektansi } \\
\varnothing \quad= & \text { Sudut elevasi matahari }
\end{aligned}
$$

\section{b. Cropping}

Cropping adalah proses memotong citra yang bertujuan untuk memilih area yang diinginkan sehingga pemrosesan data menjadi lebih fokus pada daerah yang diteliti. Proses cropping dilakukan pada kawasan Teluk Benoa menggunakan data polygon yang diperoleh dengan menggunakan metode digitasi on screen dengan acuan peta menggunakan kombinasi kanal tampak mata yaitu merah (kanal 4), hijau (kanal 3), dan biru (kanal 2).

Digitasi on screen pada dasarnya adalah melakukan tracing (menelusuri) dan mengeblat objek-objek yang ada di permukaan bumi yang tampak di peta. Objek-objek tersebut ditelusuri dengan mengklik titik, garis dan poligon (area) dari objek permukaan bumi.

\section{c. Perhitungan rata-rata nilai reflectrance}

Perhitungan rata-rata nilai reflectrance dilakukan dengan menggunakan persamaan 3 pada sensor OLI.

$$
\overline{\rho \lambda^{\prime}}=\frac{\sum \rho \lambda^{\prime}}{n}
$$

Keterangan:

$$
\begin{array}{ll}
\rho \lambda^{\prime} & =\text { Rata-rata nilai reflectance } \\
\rho \lambda^{\prime} & =\text { nilai reflectance } \\
\mathrm{n} & =\text { jumlah pixel }
\end{array}
$$

\section{d. Analisis Data}

Analisis statistika dengan menghitung nilai korelasi antar parameter (rata-rata nilai reflectance dan elevasi pasang surut) digunakan untuk mengetahui respon Landsat 8 terhadap kondisi Teluk Benoa. Sebaran nilai reflectant setiap band (band $1-7$ ) dapat diketahui dengan analisis spasial.

\section{Hasil dan Pembahasan}

\subsection{Sebaran nilai reflectance band 1-7}

Data polygon area penelitian yang disesuiakan dengan hasil cropping citra Landsat 8 disajikan pada Gambar 3. Nilai reflectance masing-masing band dari band $1-7$ pada citra Landsat 8 dihitung berdasarkan segementasi badan air polygon Gambar 3. Distribusi nilai reflectance citra Landsat 8 di Teluk Benoa dapat dilihat pada Gambar $4-10$. 


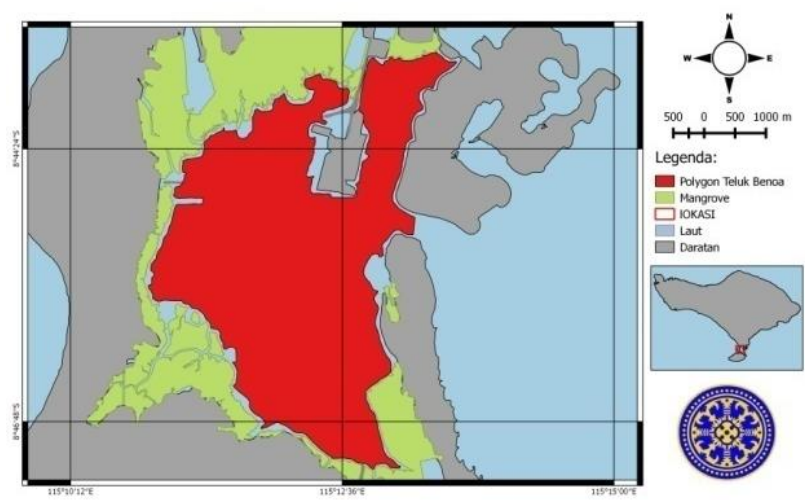

Gambar 3. Polygon Teluk benoa

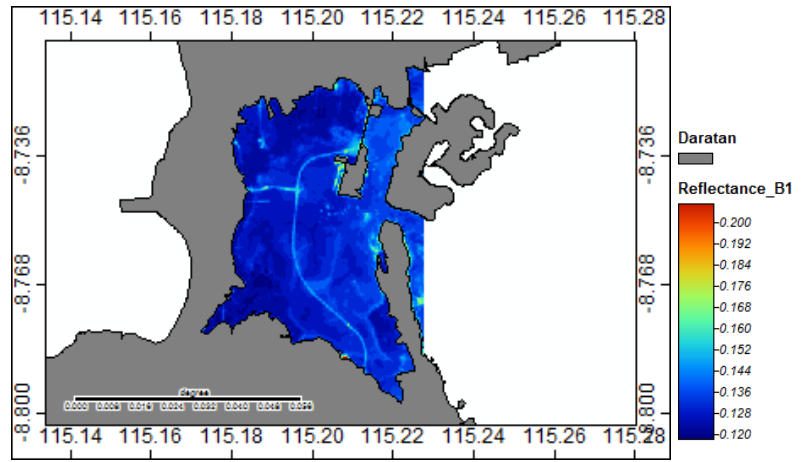

Gambar 4. Reflectance B1

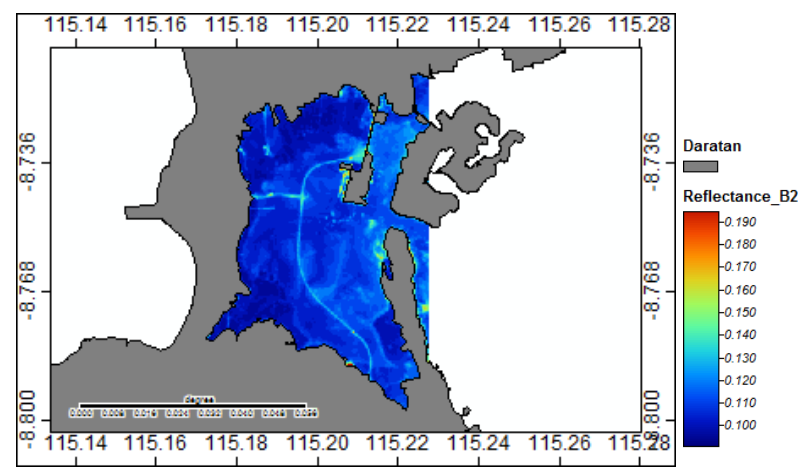

Gambar 5. Reflectance B2

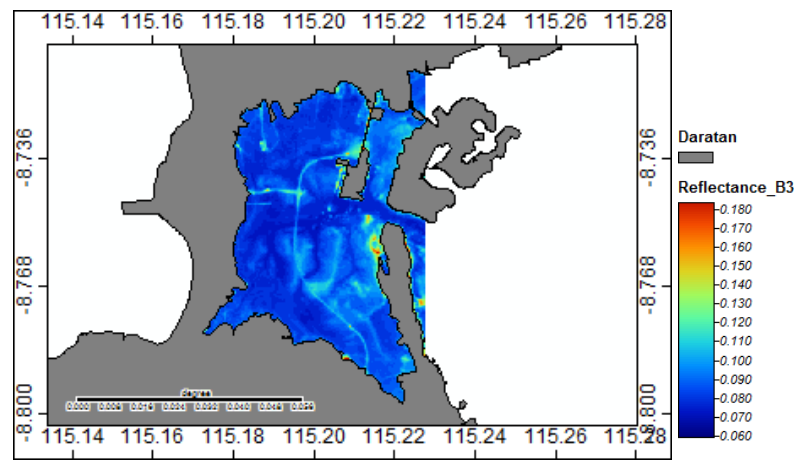

Gambar 6. Reflectance B3

Dari Gambar 4-10 dapat dilihat bahwa terdapat variasi nilai reflectant dari masing-masing band pada citra Landsat 8. Nilai pantulan spectral B8, B9, B10 dan B11 tidak disajikan dan dibahas lebih lanjut pada penelitian ini mengingat fungsinya spesifik untuk panchromatic dan analisis termal. Perbandingan ini mengungkapkan bahwa penggambaran terbaik dari badan air diperoleh pada panjang gelombang near infrared dan short wave infrared dalam rentang $0.85-2.29$ micrometer.

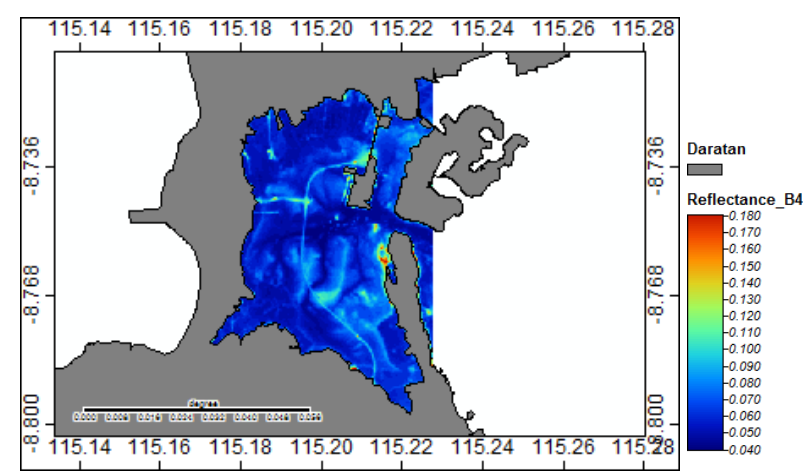

Gambar 7. Reflectance B4

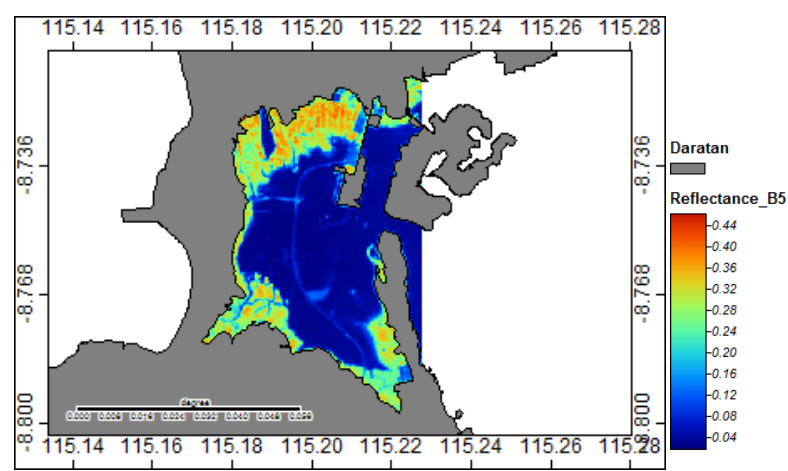

Gambar 8. Reflectance B5

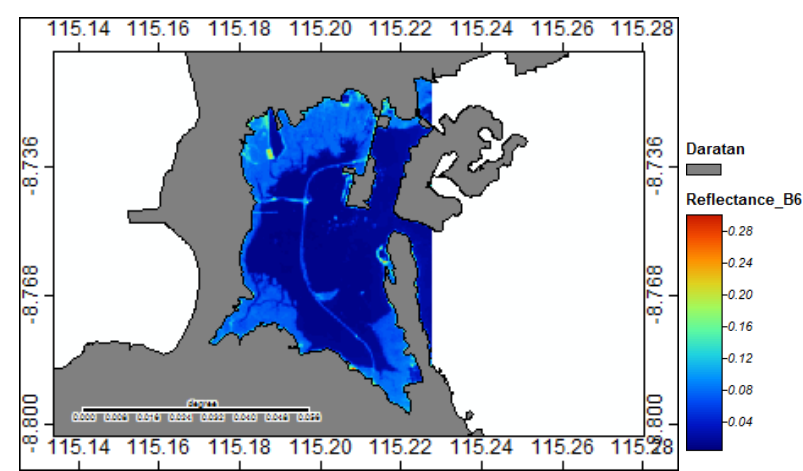

Gambar 9. Reflectance B6

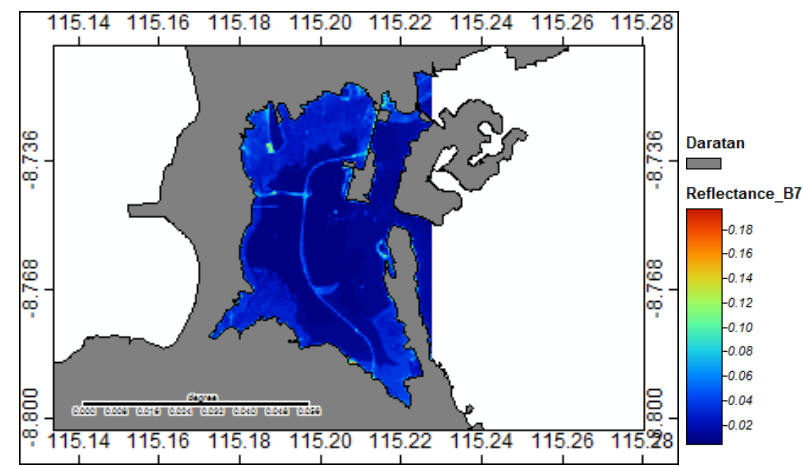

Gambar 10. Reflectance B7 


\subsection{Kondisi Pasang Surut Teluk Benoa}

Secara geomorfologi bentuk Teluk Benoa relatif datar dan sangat dangkal. Kondisi kontras ditunjukkan pada saat pasang bila dibandingkan dengan saat surut. Pada saat pasang air menggenangi seluruh badan air dan area mangrove. Namun saat surut kondisi perairan seperti hamparan pasang surut dengan level air sangat rendah. Perbedaan kondisi level air saat pasang dan surut ini berdampak pada karakteristik ekosistem yang terbentuk. Pada saat air laut pasang Teluk Benoa merupakan sebuah ekosistem perairan teluk yang mempunyai produktifitas primer tinggi. Saat surut Teluk Benoa menjadi habitat bagi berbagai jenis kerang-kerangan dan krustase yang merupakan komoditas nelayan setempat.

Data elevasi pasang surut di sekitar area penelitian pada saat citra Landsat diakusisi dapat dilihat pada Gambar 11 dan elevasi pasang surut untuk seluruh data Landsat disajikan pada Tabel 2. Elevasi pasut saat citra Landsat diakuisisi bervariasi mulai dari $-0.121 \mathrm{~m}$ sampai $0.857 \mathrm{~m}$. Jangkauan dari elevasi terendah hingga tertinggi adalah $0.978 \mathrm{~m}$. Hal ini menunjukkan adanya perbedaan kondisi perairan saat citra Landsat terakuisisi.

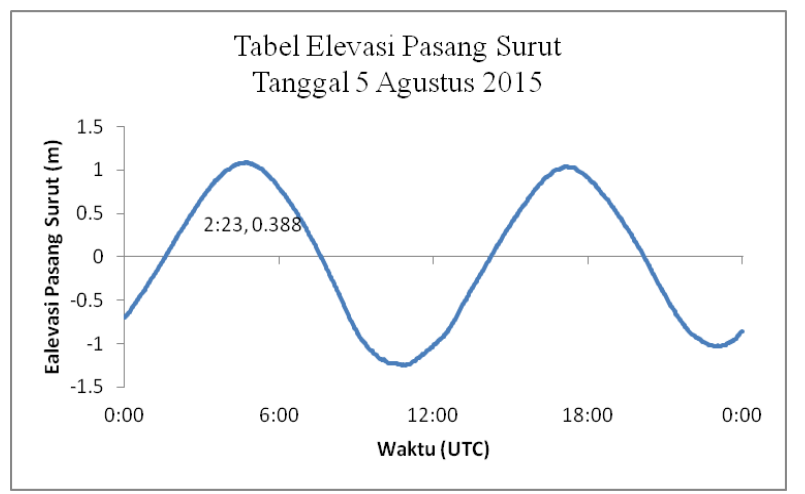

Gambar 11. Contoh data elevasi pasang surut pada saat akusisi citra Landsat 5 Agustus 2015

Tabel 2

Elevasi pasang surut untuk seluruh data Landsat 8 yang digunakan dalam penelitian ini

\begin{tabular}{ccr}
\hline No & $\begin{array}{c}\text { Tanggal Akusisis } \\
\text { Landsat Teluk Benoa }\end{array}$ & $\begin{array}{c}\text { Elevasi Pasut } \\
(\mathrm{m})\end{array}$ \\
\hline 1 & $27 / 03 / 2014$ & -0.121 \\
2 & $14 / 05 / 2014$ & 0.857 \\
3 & $10 / 02 / 2015$ & 0.043 \\
4 & $05 / 08 / 2015$ & 0.388 \\
5 & $21 / 08 / 2015$ & 0.073 \\
6 & $30 / 03 / 2015$ & 0.008 \\
7 & $15 / 04 / 2015$ & -0.118 \\
8 & $01 / 05 / 2015$ & 0.307 \\
\hline
\end{tabular}

\subsection{Hubungan Pantulan Spektral dengan pasang surut}

Hubungan antara nilai rata-rata reflektan dan elevasi air untuk band 1-7 di area Teluk Benoa ditunjukkan oleh Gambar 12 - 18. Grafik korelasi antara elevasi pasut dengan nilai rata-rata reflektan menunjukkan tren yang tidak begitu jelas. Namun nilai korelasi tertinggi disajikan pada area cahaya tampak atau band visible B1 dan B2 dengan nilai korelasi 0.65 dan 0.67 bila dibandingkan dengan NIR dan SWIR area (B5, B6 dan B7). Hasil ini mengindikasikan permukaan air tidak berkontribusi significant terhadap variasi nilai reflektan pada citra Landsat 8. Fluktuasi nilai reflektan terjadi lebih karena adanya materi sediment, lumpur atau vegetasi di air seperti yang didiskusikan pada penelitian sebelumnya (Krezhova et al., 2007; Fan et al., 2009; Gangale et al., 2010).

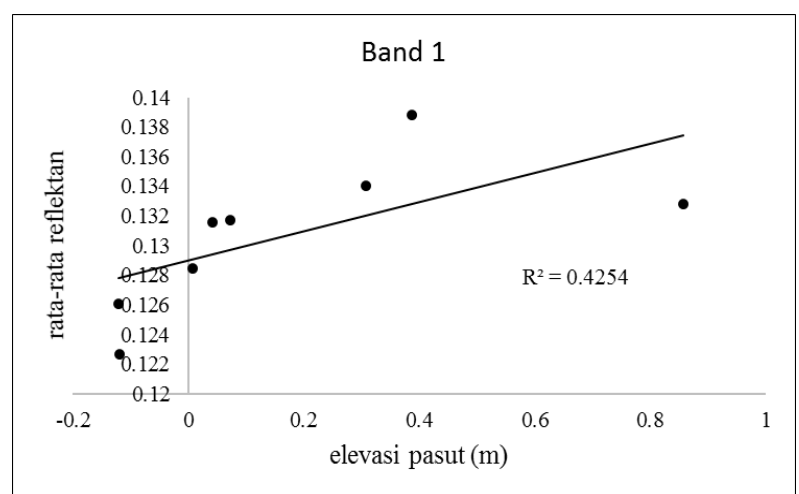

Gambar 12. Hubungan nilai rata-rata reflektan band 1 Citra Landsat 8 dengan elavasi pasut

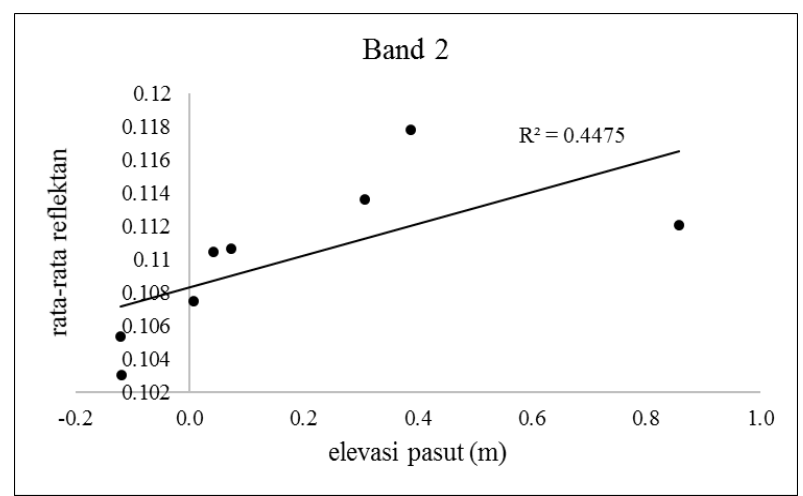

Gambar 13. Hubungan nilai rata-rata reflektan band 2 Citra Landsat 8 dengan elavasi pasut

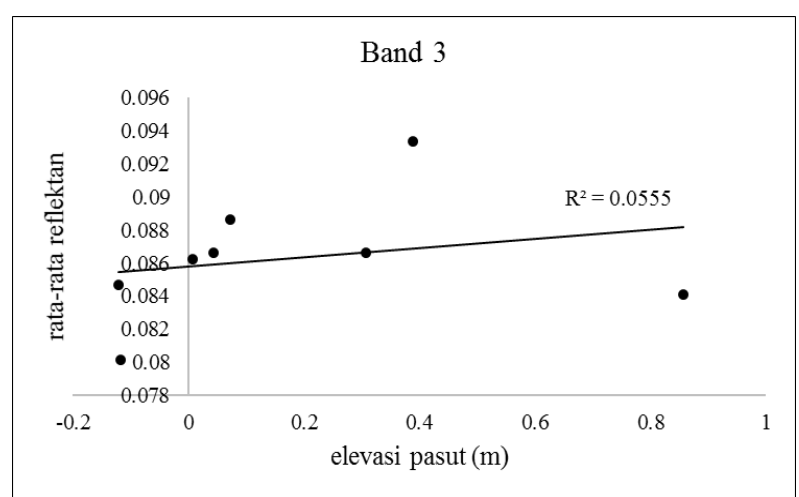

Gambar 14. Hubungan nilai rata-rata reflektan band 3 Citra Landsat 8 dengan elavasi pasut 


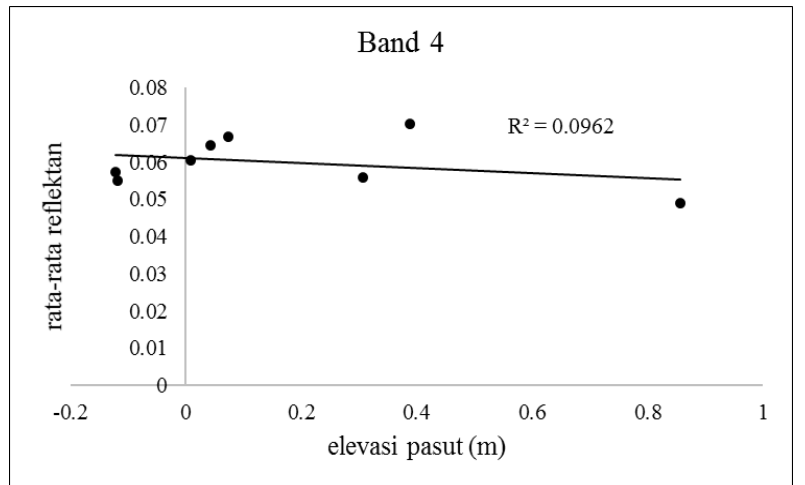

Gambar 15. Hubungan nilai rata-rata reflektan band 4 Citra Landsat 8 dengan elavasi pasut

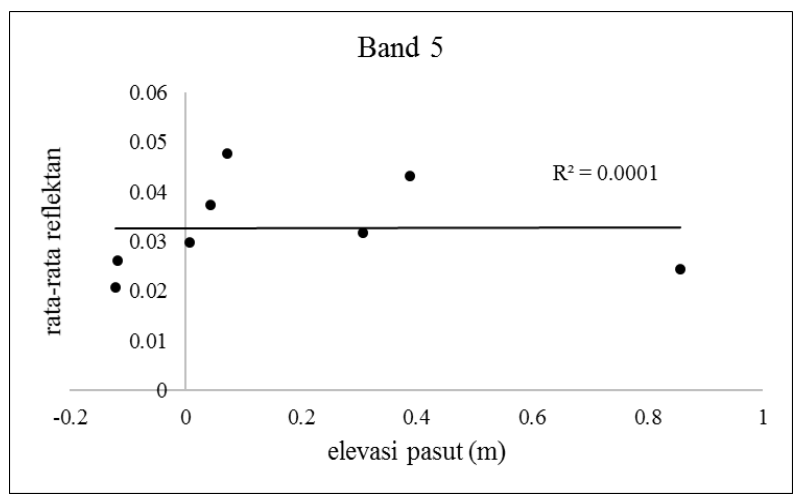

Gambar 16. Hubungan nilai rata-rata reflektan band 5 Citra Landsat 8 dengan elavasi pasut

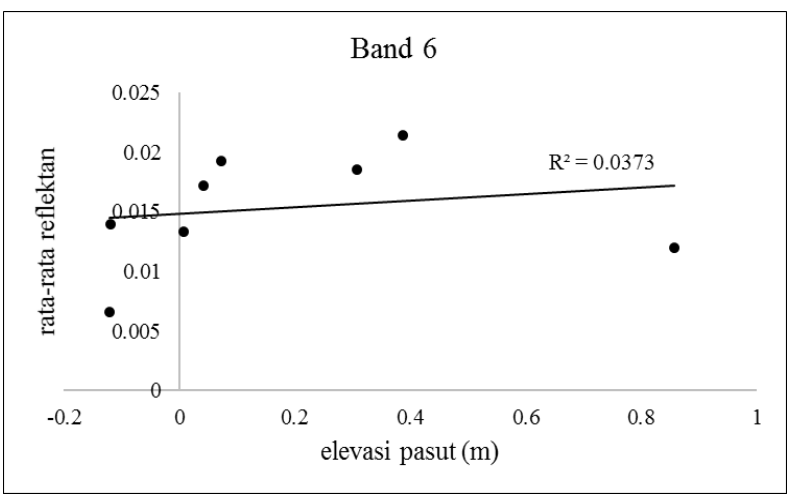

Gambar 17. Hubungan nilai rata-rata reflektan band 6 Citra Landsat 8 dengan elavasi pasut

\section{Simpulan dan Saran}

Hubungan respon spektral (reflektan) dengan fluktuasi elevasi pasut di Teluk Benoa telah dilakukan dengan menggunakan citra Landsat 8. Hasil penelitian menunjukkan bahwa bahwa pada saat citra Landsat diakusisi, Teluk Benoa memiliki elevasi pasang surut dari $-0,121$ ke 0,857 . Spektral respon mengindikasikan adanya variasi nilai reflektan badan air dari masing-masing band pada citra Landsat 8. Respon spektral area perairan menunjukkan kontras antara zona cahaya tampak dan inframerah. Tidak ada korelasi yang jelas antara variasi pasang surut air laut dan nilai replektan pada zona inframerah; hal ini menunjukkan bahwa kandungan material pada air laut lebih berpengaruh terhadap variasi nilai reflektan pada citra Landsat 8 khususnya kondisi sedimen dan vegetasi dalam air seperti yang ditunjukkan pada area spektrum cahaya tampak dengan korelasi sedang 0,65 (B1) dan 0,67 (B 2). Penelitian lanjutan dengan mempertimbangkan variasi kedalaman dan kandungan bahan kimia pada air laut perlu dilakukan untuk mengetahui hubungan nilai spektral terhadap kualitas perairan di Teluk Benoa.

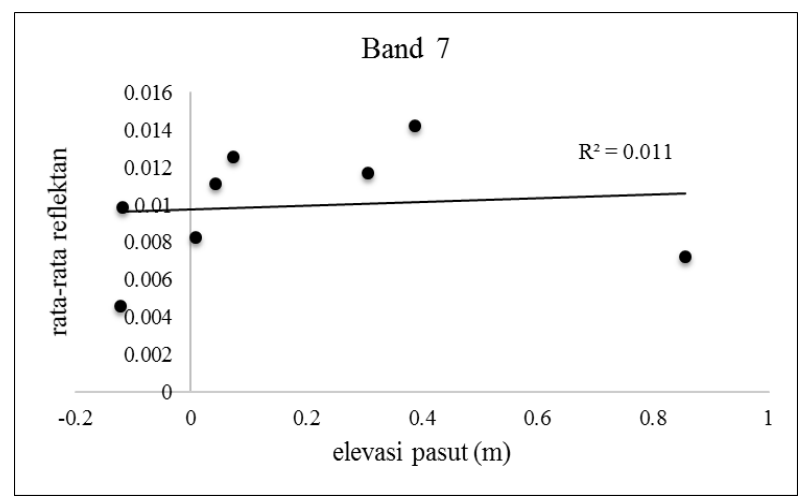

Gambar 18. Hubungan nilai rata-rata reflektan band 7 Citra Landsat 8 dengan elavasi pasut

\section{Ucapan terimakasih}

Penulis mengucapkan terimakasih kepada Laboratorium Remote Sensing dan GIS, Fakultas Kelautan dan Perikanan Universitas Udayana yang telah mengijinkan menggunakan Laboratorium dalam analisis data. Selain itu, penulis mengucapkan terimakasih terhadap NASA dan IOC atas data yang telah penulis gunakan.

\section{Daftar Pustaka}

Chang, C. I., Chakravarty, S., Chen, H. M., \& Ouyang, Y. C. (2009). Spectral derivative feature coding for hyperspectral signature analysis. Pattern recognition, 42(3), 395-408.

Decker, A. G., Malthus, T. J., Wijnen, M. M., \& Seyhan, E. (1992). The effect of spectral bandwidth and positioning on the spectral signature analysis of inland waters. Remote Sensing of Environment, 41(2), 211-225.

Doxaran, D., Froidefond, J. M., Lavender, S., \& Castaing, P. (2002). Spectral signature of highly turbid waters: Application with SPOT data to quantify suspended particulate matter concentrations. Remote sensing of Environment, 81(1), 149-161.

Fan, C., Schulze-Makuch, D., Xie, H., \& Lu, N. (2009). Investigation of water signatures at gully-exposed sites on Mars by hyperspectral image analysis. Planetary and Space Science, 57(1), 93-104.

Gangale, G., Prata, A. J., \& Clarisse, L. (2010). The infrared spectral signature of volcanic ash determined from highspectral resolution satellite measurements. Remote sensing of environment, 114(2), 414-425.

Hendrawan, I. G., \& Asai, K. (2014). Numerical study on tidal currents and seawater exchange in the Benoa Bay, Bali, Indonesia. Acta Oceanologica Sinica, 33(3), 90-100.

Hendrawan, I. G., \& Asai, K. (2010). Study of suspended sediment distribution using numerical model and satellite 
data in Benoa Bay-Bali, Indonesia. International Journal of Remote Sensing and Earth Sciences, 5, 84-91.

Hendrawan, I. G., Uniluha, D., \& Maharta, I. P. R. F. (2016). Karakteristik Total Padatan Tersuspensi (Total Suspended Solid) Dan Kekeruhan (Turbidity) Secara Vertikal Di Perairan Teluk Benoa, Bali. Journal of Marine and Aquatic Sciences, 2(1), 29-33.

Krezhova, D. D., Yanev, T. K., Pristavova, S. D., \& Pavlova, P. E. (2007). Discrimination of rock types and main rockforming components in Bulgarian territories through spectral reflectance characteristics. Advances in Space Research, 39(1), 179-184.

Marhaba, T. F., Borgaonkar, A. D., \& Punburananon, K. (2009). Principal component regression model applied to dimensionally reduced spectral fluorescent signature for the determination of organic character and THM formation potential of source water. Journal of hazardous materials, 169(1), 998-1004.
Rachman, H. A., Hendrawan, I. G., \& Putra, I. D. N. N. (2016). Studi transpor sedimen di Teluk Benoa menggunakan pemodelan numerik. Jurnal Kelautan: Indonesian Journal of Marine Science and Technology, 9(2), 144-154.

Roy, D. P., Wulder, M. A., Loveland, T. R., Woodcock, C. E., Allen, R. G., Anderson, M. C., Helder, D., Irons, J.R., Johnson, D.M., Kennedy, R., Scambos, T.A., Schaaf, C. B., Schott, J.R., Sheng, Y., Vermote, E.F., Belward, A.S., Bindschadler, R., Cohen, W.B., Gao, F., Hipple, J.D., Hostert, P., Huntington, J., Justice, C.O., Kilic, A., Kovalskyy, V., Lee, Z. P., Lymburner, L., Masek, J.G., McCorkel, J., Shuai, Y., Trezza, R., Vogelmann, J., Wynne, R.H., Zhu, Z. (2014). Landsat-8: Science and product vision for terrestrial global change research. Remote Sensing of Environment, 145, 154172.

Zanter, K. (2016). Landsat 8 (L8) Data users handbook, version 2.0. Sioux Falls, South Dakota, US; Department of the Interior, U.S. Geological Survey (USGS).

(C) 2016 by the authors; licensee Udayana University, Indonesia. This article is an open access article distributed under the terms and conditions of the Creative Commons Attribution license (http://creativecommons.org/licenses/by/3.0/). 